DOI: https://doi.org/10.15407/preislamic2021.02.009

UDC 94:[737.1.05.046:336.742](37-21)

\title{
GODDESS TYCHE IN THE COINAGE OF THE CITIES OF THE ROMAN PROVINCE OF ASIA
}

\author{
A. Yu. Baukova \\ $\mathrm{PhD}$ (History) \\ Assistant Professor \\ Ivan Franko National University of Lviv \\ 1, Universytets'ka Str., Lviv, 79000, Ukraine \\ anastasiya.baukova@Inu.edu.ua
}

Ancient coins are an interesting source for studying cultural and historical processes in the Mediterranean. The transformation of Greek territories into part of the Roman state, the formation of a holistic system of money circulation and a single market contributed to the unification of coin types and styles. Despite this, representatives of the ancient Greek pantheon and local deities were often used in decoration. Interestingly, over time, some traditional deities were less commonly used in this matter. Instead, the goddess Tyche belongs to those deities, whose image from the little known became common in Roman times. This was probably due to the very incarnation of the goddess. She was the patron saint of luck, prosperity, providence and destiny. However, in the first centuries $\mathrm{AD}$, she became the patron of cities and symbolized their prosperity. This evolution can be traced in the coinage of the cities of the province of Asia, which was a conglomeration of cities of the former kingdom of Pergamum. The image of Tyche-Fortune as a personification of the variability of choice was widely used in provincial coinage, in various denominations. Unlike other territories, in Asia the bust of the goddess was almost never depicted on the obverse. The most popular were two types of reverse decoration: Tyche with a cornucopia and a rudder in her hands and a bust of the goddess in a crown of city walls. The image of Tyche was especially often used by magistrates of the cities of Lydia, Mysia, Troas and other regions of the province of Asia in coinage in honor of Caracalla, Gordian III, Julia Domna, Elagabalus, Severan dynasty, Trajan etc. Coinage was a means of combating with hyperinflation and coin devaluation. The goddess Tyche was especially often used in urban coinage during the Crisis of the III century, which especially emphasizes the peculiarities of economic relations and the lack of money supply at that time. In general, the analysis of coins shows the evolution of the image of the goddess from the patroness of cities to the emphasis on the impermanence of the goddess, who distributes good and evil despite the merits of people or cities. Also, in the provincial coinage, her image emphasized that Tyche, in the guise of Fortune or Nemesis, was the goddess of choice and just retribution.

Keywords: goddess Tyche, the Roman province of Asia, coinage, temple, countermark, emperors, Imperial Crisis

\section{А. Ю. Баукова}

\section{БОГИНЯ ТЮХЕ В МОНЕТНОМУ КАРБУВАННІ МІСТ РИМСЬКОЇ ПРОВІНЦІЇ АЗІЯ}

Античні монети є цікавим джерелом для вивчення культурно-історичних процесів у Середземномор'ї. Перетворення грецьких територій на частину Римської держави, формування цілісної системи грошового обігу та єдиного ринку сприяли уніфікації монетних типів та стилів. Незважаючи на це, представники загальногрецького пантеону та локальні божества доволі часто використовувались в оздобленні 
монет римського часу, карбованих за межами Європи. Цікаво, що з плином часу деякі традиційні божества рідше використовувались у цій справі. Натомість, богиня Тюхе належить до тих божеств, чий образ, раніше малознаний, у римський час став загальновживаним. Це, ймовірно, було пов'язано із самою іпостассю богині. Вона була покровителькою удачі, добробуту, провидіння та долі. Примітно, що Тюхе була уособленням не доброї долі, а тої долі, яку особа чи місто заслуговувало. Однак у перших століттях нашої ери в іпостасі Тюхе на перший план виступає покровительство містам, і богиня стає символом їхнього процвітання. Цю еволюцію й можна простежити в монетному карбуванні міст провінції Азія, яка була саме конгломератом міст-полісів колишнього Пергамського царства. Зберігаючи традицію давньої автономності, магістрати різних міст у напівавтономному та автономному карбуванні використовували образ Тюхе.

Тюхе (Тіхе) в грецькій міфології була богинею випадку. За різними варіантами міфу вважалась донькою Океана, Прометея або навіть Зевса. Матір'ю Тюхе була Тетія (Hesiod, Theogony 346). Ця обставина вказує на дуже давнє походження уявлень про персоніфікацію долі, щастя та випадку. Гнучкість грецького пантеону та його динамічний розвиток сприяли деталізації образу божеств та трансформації уявлень. Не стало винятком і уявлення про персоніфікацію долі та ії визначеності. Інтерпретація іконографії ускладнюється наявністю інших божественних сил, які визначали долі людей і богів. Передусім ідеться про мойр. Сама назва цих богинь moirai означає “частка, доля”. Стародавні греки вважали, що мойр було троє: Клото, Лахезіс та Антропос - і вони визначали все життя людини. Якщо Клото (Прядильниця) ткала нитку життя, Лахезіс (Дарувальниця) вела ії через усі мінливості долі, то Антропос (Невідворотна) перерізала нитку, що й було кінцем життя. Саме друга 3 мойр, Лахезіс, і цікавить нас як уособлення доброго випадку та прихильності долі (Paus., VII.26, §3). Оскільки і Лахезіс, і Тюхе належали до дуже давніх божеств, то їхній художній образ почав створюватись аж із часів пізньокласичної Греції. Тюхе була навіть не божеством, а персоніфікацією абстрактного поняття, подібно до Ананке (Необхідність), Адікії (Несправедливість), Діке (Справедливість), Арете (Відвага) тощо. На перших етапах існування міфологічного світогляду такі персоніфікації не потребували художнього втілення. Здебільшого інформацію про звернення до богині (богинь) долі містять твори поетів. До найдавніших творів належить ода Піндара, де автор звертається до Тюхе як однієї з мойр, що є захисницею міст (Pind., Nemean Ode 12.1ff) і дочкою Зевса Визволителя (Pind., Hymn. fr. 39). Алкман у середині VII ст. до н. е. писав, що Тюхе є сестрою Ейномії (Доброго порядку) та Пейто (Переконання) і донькою Прометея (Alcman, Fragment 64). У процесі формування загальногрецької системи вірувань в Афінах та інших містах почали вшановувати Добру Тюхе (Agathe Tyche) як покровительку міста [Smith $2003,25]$. Хоча й надалі існувала досократична традиція неперсоніфікації Тюхе. У "Природі речей” Емпедокл зазначав, що "все задумано за волею Тюхе" (DK, 1 В $103)$, а із фрази Одіссея "інакше ми будемо вважати Долю богом, а богів сладбшими за Долю" (Eur., Cycl. 607) в момент осліплення Поліфема в “Циклопі” Евріпіда можна побачити розуміння Тюхе важливою силою, але не божеством. Лише згодом, в елліністичну добу, а особливо в римський час, остаточно оформились іконографія образу Тюхе та іiї функції. Також частішими були випадки міських культів на честь Тюхе. 
Щодо досліджуваної території, то монетний матеріал засвідчує, що найраніше погруддя Tюхе в короні з міських мурів використано в оздобленні монет IV ст. до н. е. лідійського міста Гіпайпи (SNG von Aulock 2960) $)^{1}$ (мал. 1).
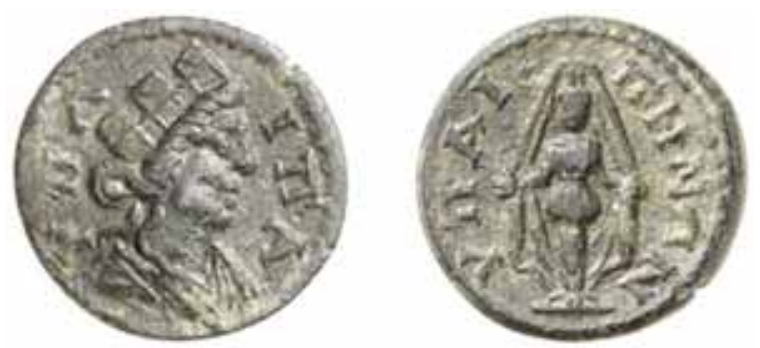

Мал. 1. Одне з найраніших зображень погруддя Тюхе на монеті з Гіпайпи

Оскільки Гіпайпа була центром вшанування перської богині Анахіти (Анаїти чи Артеміди Анаїти в греко-романському звучанні) [Mark Joshua], то в оздобленні монет часто траплялось поєднання постаті Тюхе та Артеміди Анаїти (мал. 2).
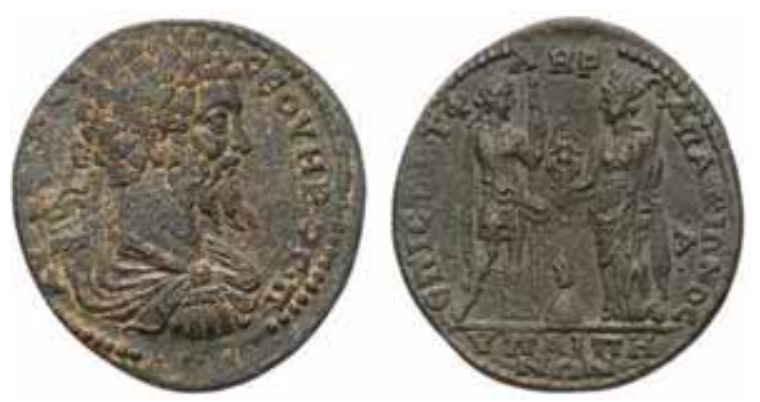

Мал. 2. Зображення Тюхе з культовою статуєю Артеміди Анаїти в правій руці на монеті Септимія Севера з Гіпайпи

Згодом, у другій половині II ст. до н. е., після 165 р. до н. е., як зазначається в каталогах, на срібних цистофорах Смірни також міститься погруддя Тюхе в короні 3 міських мурів (BMC 4v, SNG von Aulock 2161) (мал. 3).
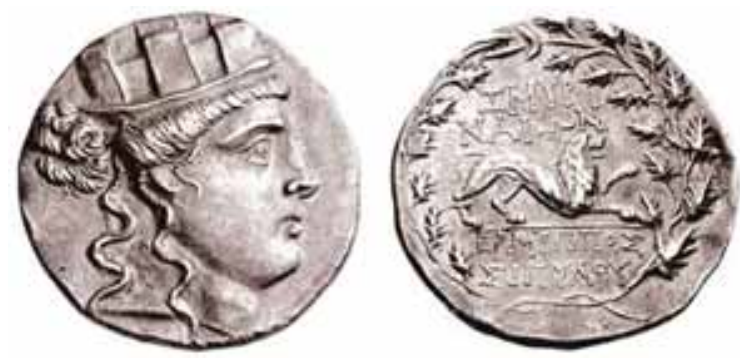

Мал. 3. Погруддя Тюхе в короні з міських мурів на срібному цистофорі зі Смірни

Упродовж II-I ст. до н. е. погруддя Тюхе в калафі та короні з міських мурів прикрашало монети Сард цивільного карбування (BMC 49-52; GRPC Lydia 345). У розумінні образу Тюхе як захисниці міста може допомогти прочитання легенди IEPA ГЕРМН на монетах II-III ст. н. е. з Герме в Мiciї, де аверс прикрашений погруддям богині (BMC 12, SNG von Aulock 1093; SNG Copenhagen 132; Weber 6807).

\footnotetext{
${ }^{1}$ Тут і далі світлини монет подано за: https:/www.wildwinds.com/coins/
} 
А. Ю. Баукова

Якість монет та ретельність деталізації зображення визначались їхньою купівельною вартістю і престижністю. Тим самим підкреслювався і статус зображеного божества. Слід зауважити, що, незважаючи на простоту зображення мурів, аналіз цієї деталі образу дає змогу простежити певні деталі оздоблення брам, їхню кількість, архітектурні деталі тощо. Наприклад, на монетних зразках зі Смірни башт $є$ дві, і така традиція збережеться в персоніфікації Амазонки Смірни. Дві (рідше три) башти є й на монетах Мостене (Imhoof $L S 3 ; B M C$ 5; SNG von Aulock 3028; RPC 995) у Лідії, і такий головний убір подібний до діадеми, а не корони (мал. 4).
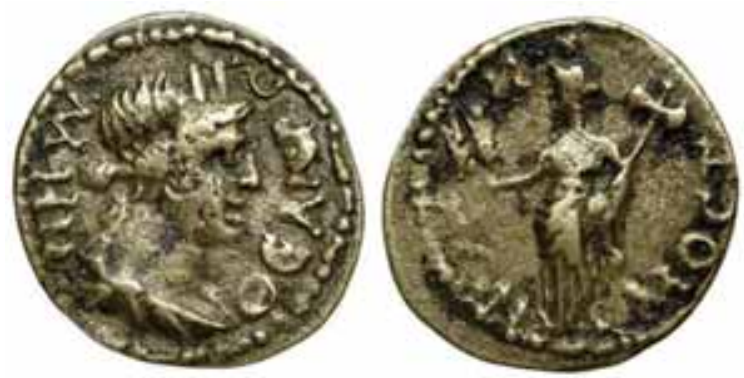

Мал. 4. Різновид корони з міських мурів у вигляді діадеми

На монетах з Герме (Місія) серед башт корони можна побачити сліди брам, вирізьблених майстром ( $S N G$ von Aulock 7216), або деталі поверхів башт (BMC 12, $S N G$ von Aulock 1093; SNG Copenhagen 132; Weber 6807). На монетах напівавтономного карбування 138-268 рр. н. е. з Александрії в Троаді погруддя Тюхе не вирізнялось тонкістю деталізації та витонченості рис обличчя, натомість брами та башти корони прокреслені дуже ретельно, навіть незважаючи на обмежений простір монетного кола (мал. 5). Найяскравішими прикладами є SNG Tuebingen 2536 чи BMC 57.

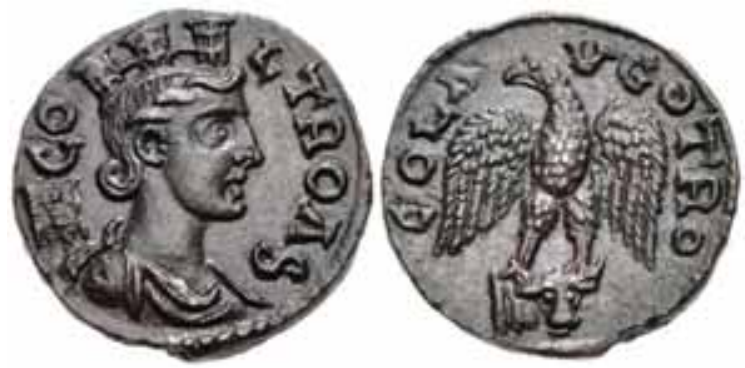

Мал. 5. Деталізація вигляду міських башт у короні Тюхе на монеті з Александрії

Монетне карбування з Александрії треба відзначити також і тому, що в ньому підкреслено, так би мовити, римськість споживачів та емітентів через поєднання погруддя Тюхе та вексилума. Сюди ж слід зарахувати монети із зображенням Капітолійської вовчиці на реверсі ${ }^{2}$. Саме такий тип обрала міська влада для оздоблення цивільного випуску бронзових монет II-III ст. н. е. (SNG Munich 65-67) (мал. 6).

${ }^{2}$ Композиція з вовчицею та близнятами в провінційному карбуванні Азії зазвичай була притаманна монетам з погруддям імператора (наприклад, Александра Севера, Фіатира (ВMC 128) чи Септимія Севера, Фіатира (BMC 77)). 


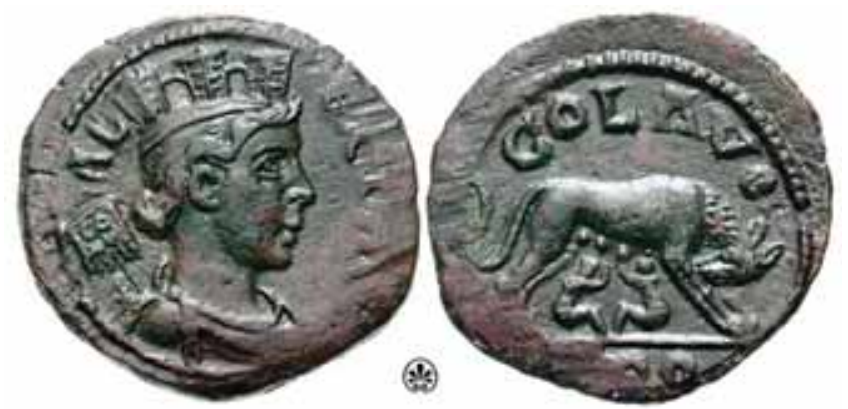

Мал. 6. Символи римського світу (вексилум, Капітолійська вовчиця) на реверсі монети із погруддям Тюхе в короні з дуже деталізованих міських мурів

Часто монети з погруддям Тюхе на звороті прикрашали зображенням орла 3 розкритими крилами, як на попередньому зображенні. Унікальним явищем можна вважати вміщення погруддя Тюхе в короні з міських мурів на реверсі бронзових монет Галієна (BMC 185) та зображення статуї богині в повний зріст із зазначеною короною на голові, з вексилумом у правій руці та культовим зображенням Аполлона Смінфейського - у лівій на монетах Александра Севера (Bellinger, Troy. A333). На монеті Доміціана ( $B M C$ 69; RPC II 943) та Каракалли (BMC 83) з Фіатири також вміщено статую Тюхе 3 короною з міських мурів. Це важливо зауважити тому, що зазвичай голова Тюхе прикрита калафом. Серед незвичних прикрас голови статуї богині є корона Ісіди на монеті 209-212 pp. н. е. із зображенням погрудь Каракалли і Гети з Філадельфії в Лідії. На зворотному боці Тюхе сидить на троні, тримає в правій руці Ніке, а у високо піднятій лівій - скіпетр зі жмутом колосся. Голова богині прикрашена дуже складним головним убором, у якому дослідники вбачають також і корону Ісіди (мал. 7) (BMC 88; GRPC Lydia 356).

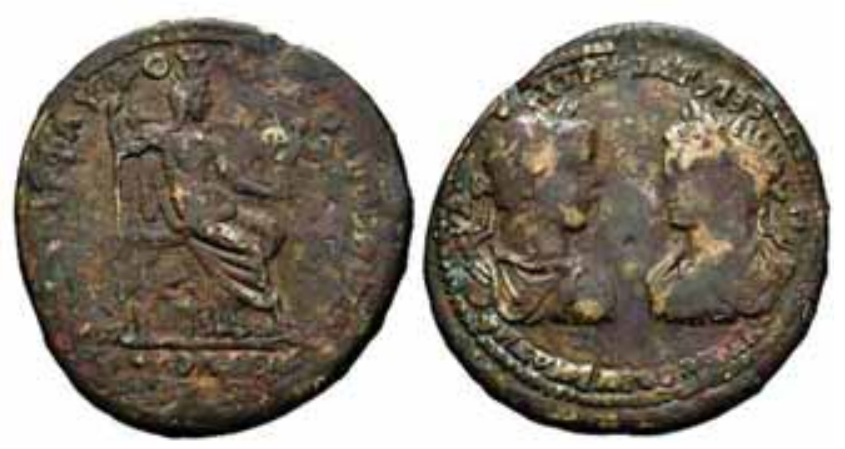

Мал. 7. Незвичний головний убір Тюхе (корона Ісіди?)

Погруддя Тюхе в короні 3 міських мурів також найчастіше вміщувалось у контрмарках у ділянці погруддя імператора чи іншого представника родини правителя. На монетах Магнезії над Сипілумом у Лідії такі приклади трапляються на монетах Гордіана III (SNG Munich 284; Waddington 5084; RPC VII 289), Отацилії Севери (SNG Copenhagen 270; BMC 86; SNG Munich 290), Гереннії Етрусцилли (Howgego 198). У таким же спосіб позначались монети і напівавтономного карбування, як-от, наприклад, на пошану сенату (Paris 643) (мал. 8). 

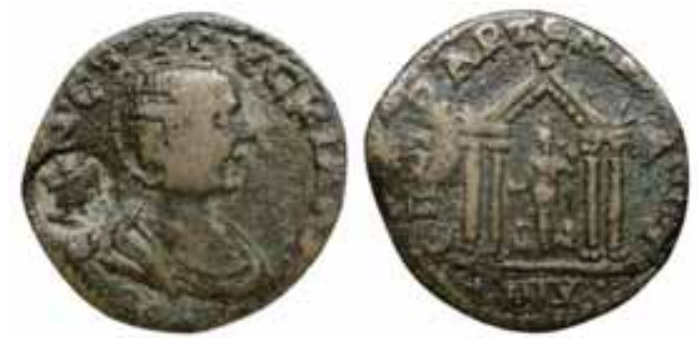

Мал. 8. Контрмарка з погруддям Тюхе в короні з міських мурів на монеті з Магнезії над Сипілумом

Завдяки вміщенню контрмарок продовжувалася “тривалість життя” наявних монет, що за умов економічної кризи II-III ст. н. е. було дешевшою альтернативою відкликанню монет, їхньому плавленню чи переробці. Контрмарки ставилися для підтвердження вартості монет, які зносилися чи для підтвердження зміни вартості монети. Також можна порушувати питання про нанесення контрмарок у випадку зміни правителів, коли новий імператор демонстрував свою владу шляхом контрмаркування монет, випущених попередниками. Такі контрмарки мали офіційний чи напівофіційний характер, однак в умовах використання бронзових монет на місцевому внутрішньопровінційному ринку характер причин не мав важливого значення. Провінційні монети з Азії є типовими прикладами контрмаркування, адже наносились такі позначки суто на бронзу.

Здебільшого штампи 3 погруддям Тюхе відзначались ретельністю деталізації штампа, однак є зразки дуже поганої якості, як-от, наприклад, на бронзових монетах I ст. до н. е. Метрополіса в Іонії (SNG Munich 663; BMC 4) (мал. 9).
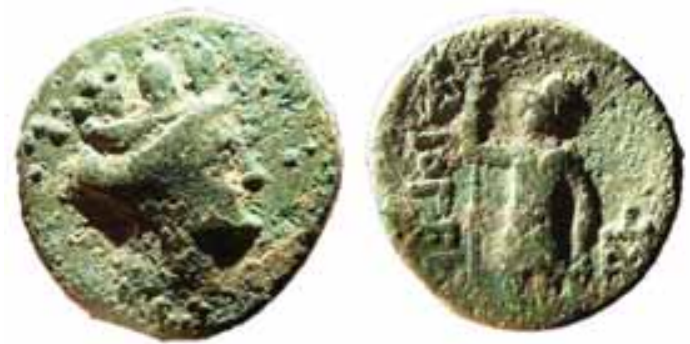

Мал. 9. Варіант якості штампа з погруддям Тюхе на монетах Метрополіса в Іонії

На серії цистофорів, карбованих у Траллах у 145-140 pр. до н. е., чи не найраніше в тодішньому Пергамському царстві вміщено статую Тюхе з рогом достатку та патерою в руках (BMC 19; SNG von Aulock 3253; GRPC Lydia S442). Згодом таке зображення стане, якщо можна так сказати, канонічним (мал. 10).
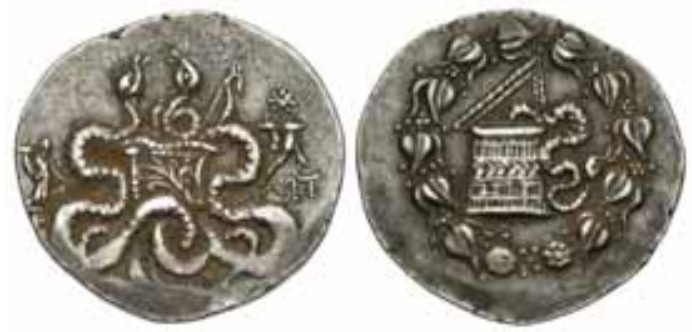

Мал. 10. Статуя Тюхе з рогом достатку та патерою в руках на цисто форі 
Ріг достатку в руках Тюхе був символом добробуту, врожаю, фізичного та духовного процвітання. Водночас, окрім Тюхе, з цим символом зображали Гею або Терру, Плутоса, німфу Маю, римську персоніфікацію достатку Абуданцію та ін. Часто в руках у статуї Тюхе містилися культові речі чи зменшені зображення інших божеств: Асклепія, Аполлона Тиримнейського, культової статуї Кори, Артеміди Ефеської, Артеміди Анаїти тощо.

Цікавим рішенням розташування об'єктів у руках богині Тюхе $\epsilon$ монета із зображенням погруддя Юлії Мези, викарбувана в Сардах у 213-228 pp. н. е. (GRPC Lydia 596). На реверсі Тюхе в короні з міських мурів стоїть, тримаючи немовля в лівій руці, а з правого боку, тримаючи Тюхе за руку, стоїть ще одна дитина (мал. 11). Така іконографія є не те що рідкісною, а унікальною для провінції Азія.

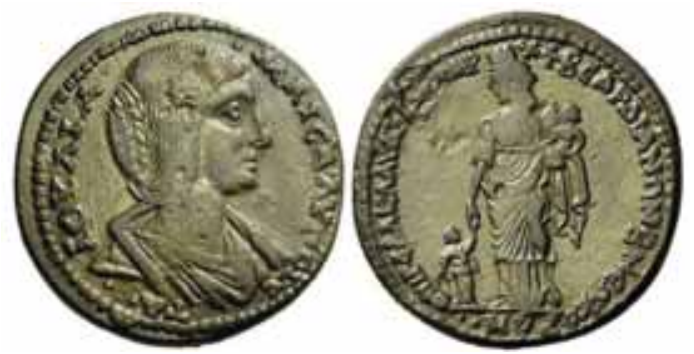

Мал. 11. Поєднання зображення богині Тюхе із двома дітьми

Для транскрипції зображення Тюхе з рогом достатку та кермом на монетах IIIII ст. н. е. у спеціальній літературі та електронних каталогах монет використовується опис "Tyche Soterios" ("Fortuna Redux"). Вперше таке поєднання двох богинь зустрічається в Res Gestae Divi Avgusti (Діяння Божественного Августа). В об’єднанні епіклез богинь провінція Азія відіграла дуже важливу роль, адже саме після повернення з цієї території Октавіан Август запровадив у Римі культ Фортуни Редукс та встановив спеціальний вівтар біля Порта Капена, брами, через яку Август в 'іххав до Риму. Споруда відома лише за монетними зображеннями, однак культ богині був важливим елементом імператорського культу загалом. В 11 пункті “Діянь" ми й зустрічаємо ось це поєднання в описі вівтаря Aram Fortunae Reducis та В

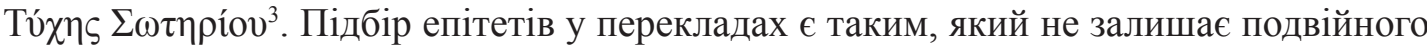
трактування. В епітеті Фортуни підкреслено їі роль провідниці, запоруки щасливого повернення. Водночас в епітеті Тюхе як рятівниці містилася значно ширша інформація, і саме цим можна пояснити вибір перекладача, який у такий спосіб підкреслив концептуальну відмінність між двома богинями [Miano 2018] $]^{4}$. Ба більше, саме так розумілась функція Тюхе в “Агамемноні” Есхіла: “і рятівна Фортуна вирішила сісти на борт нашого корабля” (Aesch. Ag. 664).

Якщо розглядати монети хронологічно за ініціаторами карбування, то найцікавішим спостереженням $\epsilon$ те, що до образу Тюхе звертались магістрати в разі цивільного, автономного чи напіватономного карбування. Такі монети ще з початку II ст. до н. е. випускались найчастіше і найраніше в Сардах у Лідії. Монетний штамп із погруддям Тюхе вирізнявся також і художністю трактування образу богині - дещо відмінна зачіска, а головне, корона у вигляді міських мурів, додатково прикрашена

\footnotetext{
${ }^{3}$ Monumentum Ancyranum (RES GESTAE DIVI AUGUSTI) - https://bit.ly/2QEUBTg

${ }^{4}$ Див: https://bit.ly/2R1g3Sn
} 
вуаллю (мал. 12). Зворотний бік таких монет прикрашено зображенням Зевса Лідійського зі скіпетром та орлом у руках (GRPC Lydia 272; RPC II 1316; SNG Munich 488). Певна кількість монет стосується псевдоавтономного карбування.

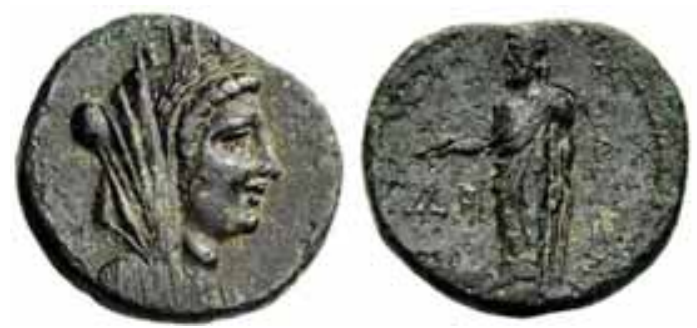

Мал. 12. Варіант оздоблення головного убору Тюхе: міські мури і вуаль

Оскільки Тюхе була прямою персоніфікацією міста, то цей образ використовувався в монетному карбуванні на честь союзів міст - так званої homonoia (гомоної). Цей механізм був розроблений ще в часи класичної Греції і допомагав уникнути міжполісних конфліктів чи засвідчував взаємодопомогу та підтримку. У провінції Азія найчастіше монети на відзначення гомоної пов'язані із союзами різних міст зі Смірною. Зазвичай композиція включала персоніфакацію Смірни як Амазонки, звернутої обличчям до постаті Тюхе, а їхні руки з'єднані в рукостисканні. Оскільки саме явище спокою та міжполісних угод в античному світі було надзвичайно важливим, то серед міфологічних постатей давньогрецького духовного світу існувало й окреме божество Гомоноя (daimona Homonoia). Це була персоніфікація згоди та одностайності, пов'язана з фіванським циклом міфів і легендарним царем Фів Огігосом ${ }^{5}$ У системі вірувань стародавніх римлян відповідником грецької Гомоної була Конкордія. У монетному карбуванні зображення Тюхе і Гомоної було дуже подібним, за винятком того, що атрибутом Тюхе було кермо, а згоду зображували 3 патерою та рогом достатку в руках. Однак для розрізнення божеств зазвичай емітент використовував позначення в легенді. Позитивний “імідж” божеств та архетипність понять, які вони уособлювали, були основою того, що їх могли поєднувати в оздобленні аверсу та реверсу однієї монети відповідно. Такими прикладами $є$ напівавтономна монета часів Принципату з Фіатири в Лідії, де на аверсі вміщено погруддя Тюхе в короні з міських мурів, а на звороті - статую Гомоної (BMC 56). Проте здебільшого поняття гомоної зазначалося в легенді, а постать богині мала все ж атрибути Тюхе.

Такі монетні типи використовували магістрати трьох лідійських міст - Філадельфії, Сард та Фіатири. Щодо часових проміжків існування, то найраніше монети із символами гомоної викарбувані у Філадельфії в часи Доміціана (81-96 рр. н. е.).

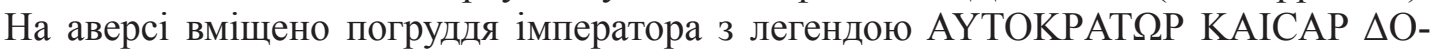
MITIANOC, а на реверсі - Тюхе (ймовірно, Філадельфіі) зі скіпетром у правій руці тисне простягнуту руку Тюхе Ефеса, яка тримає у своїй правій руці зображення Артеміди Анаїти. Композицію завершує легенда із зазначенням імені магістрату та фіксацією події: ЕПІ $\Lambda$ АГЕТА Ф $\Lambda$ ФІ $\Lambda$ А $\triangle \mathrm{E} \Lambda \Phi \mathrm{E} \omega \mathrm{N}$ KAI ЕФЕСI $\Omega N$ OMONOIA ( $R P C$ 1332; Paris 977; GRPC Lydia 212). У часи правління Коммода в Сардах (мал. 13) та у Філадельфії викарбувано монету на честь союзу цих міст з Ієраполісом у Фригії

\footnotetext{
${ }^{5}$ Див.: https://www.theoi.com/Daimon/Homonoia.html
} 
та Смірною відповідно. Легенда та зображення аверсу є майже ідентичними, а от реверс прикрашено в першому випадку двома Тюхе, які тиснуть одна одній руку, кожна 3 них тримає в руках скіпетр (GRPC Lydia 464).

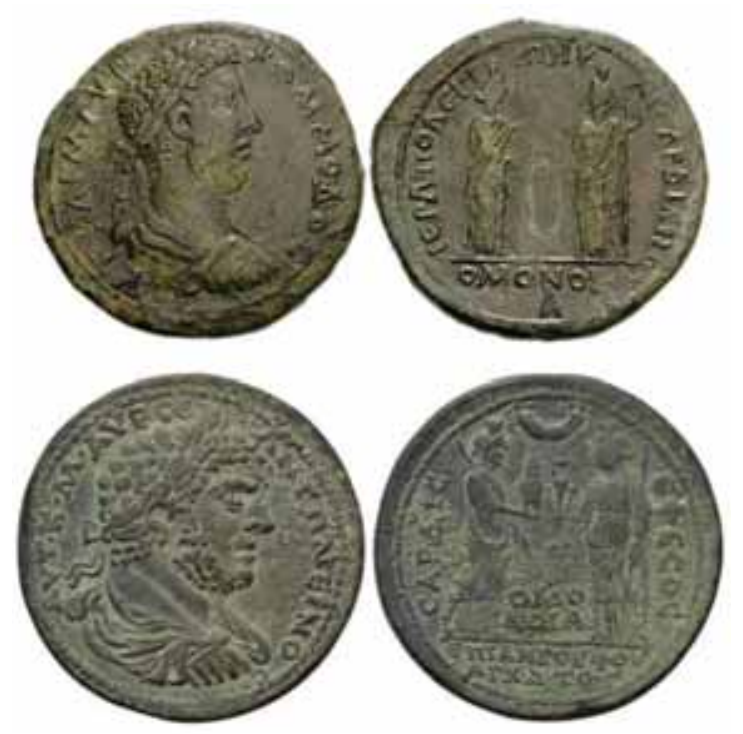

Мал. 13. Монетне відображення укладання союзу між містами

Своєю чергою, союз між Сардами та Ієраполісом у карбуванні Ієраполіса представлений не симетрично, якщо можна так сказати. По-перше, з відомих монет найближчі датуються 244-249 pр. н. е. і є свідченням напівавтономного, а не офіційного карбування. На аверсі вміщено погруддя персоніфікації демосу в оточенні легенди IEPAПО $\Lambda$ EIT $\Omega N$ K CAP $\Delta \mathrm{IAN} \Omega \mathrm{N}^{6}$, а на реверсі маленької за вагою монети $(3,29$ г) зображено Мена, що їде верхи на коні з подвійною сокирою в руках, і легенду NE $\Omega K O P \Omega N$ OMONOIA (Weber 7121; Franke-Nollé Homonoia 866-867; GRPC Lydia 344). На монеті на честь союзу Філадельфії та Смірни уособленням Смірни $є$ Немезида, а Філадельфія представлена постаттю Тюхе в полосі, з кермом та рогом достатку в руках (Imhoof KM 7A; GRPC Lydia 296). Віддзеркалення цієї події в карбуванні Смірни відсутнс. У монеті на пошанування союзу між Сардами та Ефесом, карбованої в часи правління Каракалли, персоніфікації кожного міста показані у вигляді Тюхе з відповідним культовим символом регіону - Кори для Сард та Артеміди Ефеської для Ефеса (Mionnet IV, 757; SNG Munich 551; Kraft pl. 29.6c.; FrankeNollé Homonoia 1847; GRPC Lydia 535). У карбуванні ж Ефеса цього часу є монета на честь союзу з Магнезією (Imhoof $L S 33$ ), а союз із Сардами пошанований монетою часів правління Доміціана (із двома Немезидами, а не Тюхе) (RPC 1085). Отже, можна порушувати питання про існування практики взаємного пошанування учасників союзу шляхом монетного карбування і проте, чи робилося це узгоджено та одночасно. У напівавтономному карбуванні Фіатири 238-244 pp. н. е. на пошану сенату підкреслено значення союзу зі Смірною через зображення двох персоніфікацій на реверсі. Жест рукостискання замінено зображенням палаючого вівтаря поміж

${ }^{6}$ Властиво, у монетному карбуванні Ієраполіса зустрічаємо приклади союзів між містом та Ефесом. I на таких монетах персоніфікація міст відсутня, а сам факт союзу виражений відповідною легендою з етнонімом. 
Тюхе Фіатири в короні з міських мурів 3 патерою і скіпетром та Амазонкою Смірни 3 патерою, подвійною сокирою та щитом (Imhoof $L S 33$ ). На монеті $з$ погруддям Отацилії Севери з цього ж міста союз зі Смірною показано більш прозоро - через легенду $\Theta Y A T E I P H N \Omega N$ OMONOIA K CMYPNAI $\Omega N \Sigma$ APCIMH $\Delta$ OYC та зображення Тюхе Фіатири зі скіпетром та кермом біля ніг, яка тисне руку Амазонки Смірни 3 подвійною сокирою за плечима ( $S N G$ von Aulock 3239). Огляд монет із сюжетом про укладання союзів хотілось би завершити монетою Траяна Деція з Філадельфії в Лідії (мал. 14). Складна і багатопланова композиція на реверсі монети включає в себе Тюхе зі статуєю Артеміди Анаїти в руках у центрі. Дистильний храм видніється в перспективі позаду Тюхе з лівого боку. Сама ж Тюхе оглядається назад на Діоскурів, що стоять позаду неї зліва. Значення композиції пояснюється через розлогу легенду ЕПI АYP POYФЕINOY APX OMONOIA

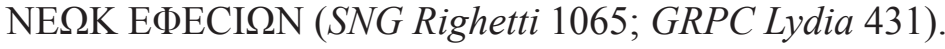

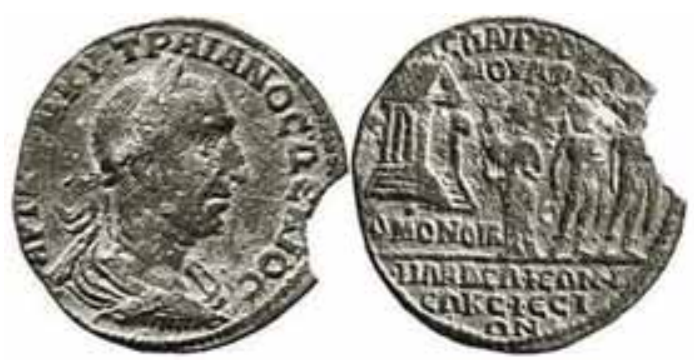

Мал. 14. Приклад складної композиції монети на честь укладання союзу міст

Інколи траплялось так, що, якщо можна так висловитись, за ціною однієї монети можна було одержати два (мал. 15) чи навіть три зображення Тюхе одночасно. На мою думку, цей тип монет з богинею є найцікавішим, після зображень Тюхе на контрмарках. Приклади монет із двома Тюхе знаходимо в напівавтономному карбуванні лідійських міст Мостене (59-79 pр. н. е.) (Hirsch 196, 1052), Гірканіса (138192 pp. н. е.) (BMC 3), Меонії (240-260 pp. н. е.) (SNG von Aulock 8234; Weber 6837; $B M C$ 30), Магнезії над Сипілумом (238-244 pp. н. е.) (BMC 36-37; SNG Copenhagen $253)^{7}$. На аверсі цих монет показано погруддя Тюхе в короні з міських мурів, а на реверсі - статую богині в калафі, з рогом достатку та кермом. Цей же дизайн використано магістратами Гірканіса для оздоблення псевдоавтономного випуску монет III ст. н. е. (SNG Copenhagen 208; SNG Munich 174).
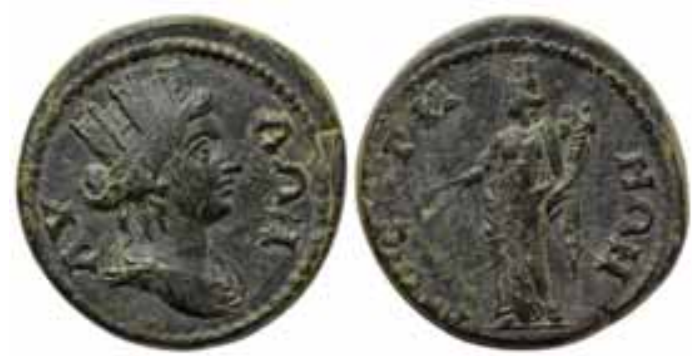

Мал. 15. Приклад оздоблення монети м. Мостене двома зображеннями Тюхе

${ }^{7}$ Стосовно карбування цього міста слід підкреслити, що реверс монет з Тюхе могла прикрашати й постать Кібели з патерою та тимпаном, у супроводі левів (BMC 39-40). Однак поза Кібели була дуже подібна за іконографією до статуї Тюхе з рогом достатку та кермом. 
Дуже цікавим прикладом є монета з Мітілени на Лесбосі, карбована на честь укладання союзу з Пергамом близько 250-268 рр. н. е. (мал. 16). Аверс монети

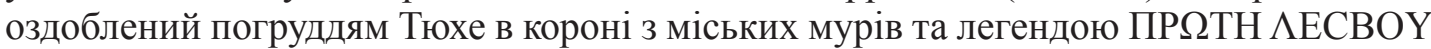
MYTI $\Lambda$ HN. Великий розмір монети, забезпечений відповідною вагою 16,6 г, дав змогу розмістити складну композицію на реверсі. Тут, як і має бути в подібних випадках, обидва міста представлені зображеннями двох Тюхе: Тюхе Пергама стоїть праворуч, тримаючи в руках статую Артеміди. Навпроти неї розміщена Тюхе Мітілени зі статуєю Асклепія в руках. Композицію довершує розгалужена легенда

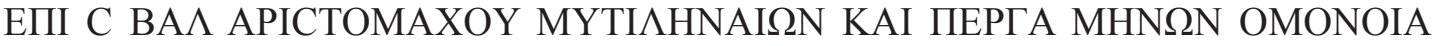
(BMC 234; SNG Munich 774).

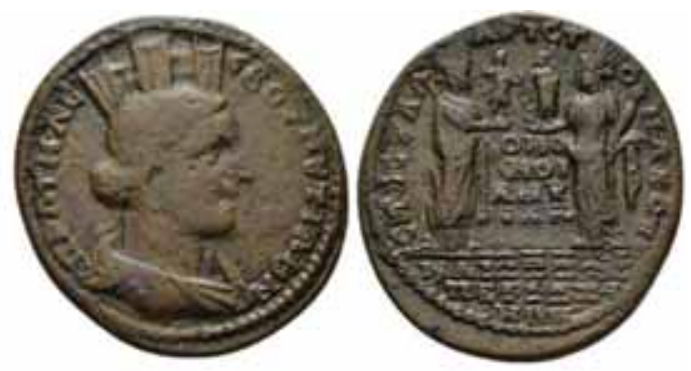

Мал. 16. Монета Мітілени з потрійним зображенням Тюхе

Хоча в античному світі $є$ небагато свідчень про існування спеціальних храмів, присвячених Тюхе, у монетному карбуванні існує серія зображень статуї Тюхе всередині тетрастильного храму. Немає певної залежності застосування такого штампа від виду емісій - автономне чи із зображенням імператора. Цікаво також, що в Смірні такі монети часів Гордіана III чи Валеріана карбувались на пошану сенату (BMC 235; BMC 239). Аналогічне зображення використовувалось і в карбуванні Магнезії над Сипілумом (Hunter 7; Walcher Coll. 2677). Але частіше ця композиція використовувалася для оздоблення реверсу монет із погруддями різних імператорів чи їхніх дружин. Найраніше до цієї композиції звернулись магістрати Гіпайпи в Лідії в часи Луція Вера (BMC 25) та Марка Аврелія (RPC IV online 1287), Каракалли (SNG von Aulock 2968) (мал. 17), Юлії Домни та Траяна Деція (Paris 525В). У Фіатирі подібна композиція прикрашає монети Септимія Севера (Ancient Caesar 30295). Аналіз усіх наявних зображень храму дає змогу виділити два типи: з напівкруглим (мал. 18) та трикутним архітравом (мал. 19). На фронтоні часто зображено округлу оздобу, яку часом ідентифікують як щит. Цікаво, що зображення погруддя Тюхе в короні з міських мурів також вміщували на фронтонах храму, зокрема на храмі Траяна в Ефесі. Зважаючи на розміри монетного штампа та масштаб деталей, цілком імовірно, що цей округлий об’єкт на монетах міг бути зображенням погруддя. Не викликає сумнівів те, що автор штампа рядом крапок на фронтоні намагався передати декоративні оздоблення карниза споруди. Власне, згаданий храм Траяна в Ефесі дуже подібний на зображену споруду не тільки загальним виглядом, а й уміщенням погруддя Тюхе в короні з міських мурів на фронтоні. Надзвичайно пишним оздобленням вирізняється зображення на монеті з погруддям Салоніни з Магнезії над Сипілумом у Лідії (SNG Munich 298). Усі чотири колони фронтону храму мають виту поверхню, архітрав також оздоблений декоративними елементами (мал. 20), що вигідно вирізняє цю монету 3-посеред інших, трохи узагальнених зображень, ймовірно, навіть цілком уявного храму. 
А. Ю. Баукова
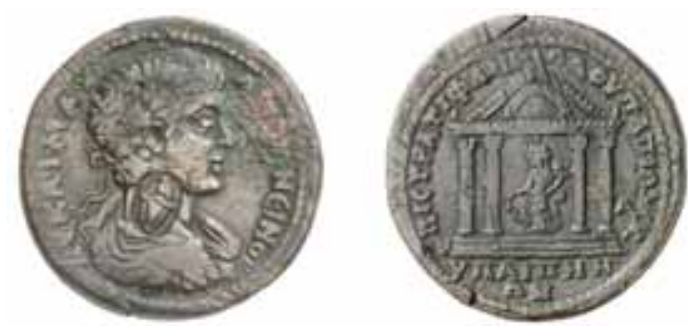

Мал. 17. Варіант тетрастильного храму зі статуєю Тюхе на монеті з погруддям Каракалли з Гіпайпи
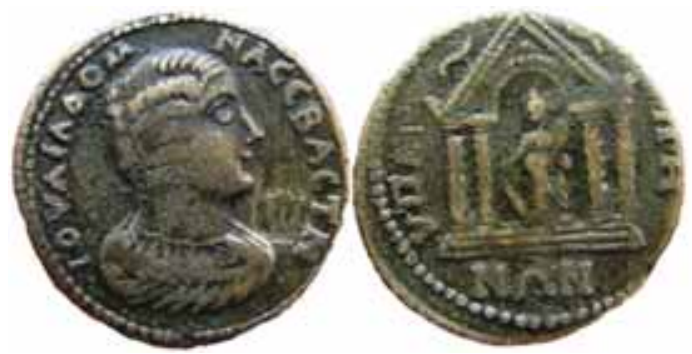

Мал. 18. Монета з Гіпайпи з погруддям Юлії Домни та тетрастильним храмом 3 напівкруглим архітравом

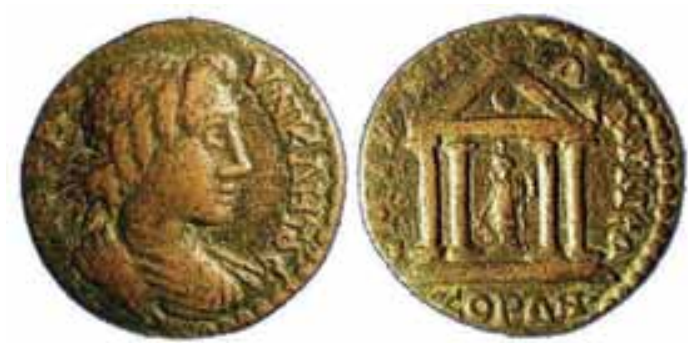

Мал. 19. Монета на пошанування сенату з тетрастильним храмом із трикутним архітравом

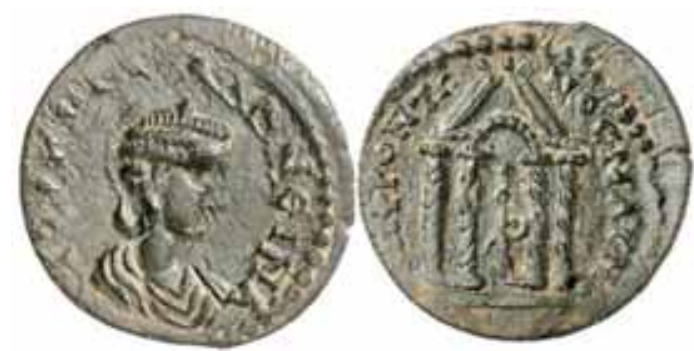

Мал. 20. Багато декорований храм зі статуєю Тюхе на монеті з Магнезії над Сипілумом

Наостанок слід зазначити важливий аспект щодо існування храмів Тюхе в загальногрецькому просторі. Низка вотивних рельєфів та присвят з Афін дає змогу припускати, що храм Тюхе існував у місті десь у районі Довгих стін, а також кілька споруд могло бути в Аттиці. Павсаній залишив інформацію про декілька статуй Тюхе роботи афінського майстра Ксенофонта і Каллістоніка у святилищі богині у Фівах (Paus., 9.16.2). Храм Тюхе зі статуєю роботи Праксителя існував і в Мегарах (Paus., 1.43.6). Про статую Тюхе роботи Праксителя, ймовірно, на агорі Афін говорили й 
Богиня Тюхе в монетному карбуванні міст римської провінції Азія

Пліній Старший та Еліан (Ael., VH 9.39; Plin., HN 36.23). Павсаній також згадує Бупала, архітектора та скульптора, що зробив статую богині Тюхе в Смірні, першим зобразивши ії з рогом кози Амалфеї в руках та з небесною кулею (Paus., 4.30.6). Однак археологічні джерела досі не дають змоги однозначно стверджувати про існування цих релігійних центрів на честь Тюхе та щодо їхнього загального вигляду.

Останнім типом монет є карбування з погруддям імператора на аверсі. Такі монети можна поділити на два типи: дещо спрощений, коли аверс прикрашає погруддя імператора чи його дружини, а реверс - “канонічна" статуя Тюхе. Цей тип представлений монетами Септимія Севера, Максиміна I, Гордіана III в Магнезії над Сипілумом (Іонія), Фаустини II та Септимія Севера в Атталеї, Александра Севера, Гордіана III, Валеріана I в Метрополісі, Каракалли, Гети, Елагабала в Салі, Юлії Домни в Апполонії, Адріана, Фаустини II в Накрасі, Каракалли, Гети, Максиміна, Отацилії Севери, Гостиліана в Тріполісі, Каракалли, Гети, Александра Севера, Гордіана III в Діос Гієроні, Александра Севера, Максиміна, Валераіна I, Галієна в Траллах, Траяна, Юлії Домни, Плаутілли, Гети в Кільбіані, Септимія Севера, Юлії Домни, Александра Севера, Юлії Маммеї, Гордіана III, Галієна, Філіпа II в Саїтті, Септимія Севера, Юлії Домни у Філадельфії, Каракалли, Елагабала, Гордіана III, Філіпа II та Галієна в Сардах. Як видно з аналізу географічних назв, до образу Тюхе здебільшого звертались магістрати лідійських міст. Розлогий перелік емітентів свідчить також і про хоч і імпліцитну, але популярність цього образу. Окремо слід згадати монету з погруддям Нерона (легенда NEP $\Omega$ N CEBACTOC) та Тюхе в короні 3 міських мурів з Магнезії над Меандром (RPC I 2460).

Однак у монетному карбуванні провінції Азія трапляється і другий тип монет, коли на реверсі вміщено складну композицію з певним сюжетом навколо особи імператора та персоніфікації долі міста. Такі монети становлять значний інтерес, адже на їхній основі реконструюються взаємовідносини міст Азії з правителем держави. Чому це важливо? А тому, що імператор для мешканців провінції був цілком уявною людиною, з якою вони ніколи не стикались. Реальним уособленням римської влади був намісник провінції, і тому саме в цьому разі монети були способом ознайомлення мешканців міст із досягненнями перших осіб держави, їхнім фізичним виглядом та важливими аспектами внутрішньої політики. Окрім того, монети як платіжний засіб розповсюджувалися в різних куточках провінції і в такий спосіб демонстрували широкому загалу корисні державні справи чи благодійність імператора, успішні рішення долі міст тощо. Передусім у цьому зв'язку слід згадати монети, викарбувані в 17-18 pp. н. е. в Магнезії над Сипілумом у Лідії на пошану імператора Тиберія, який надав допомогу лідійським містам після великого землетрусу. Благочинність імператора підкреслена легендою на аверсі TIBEPION CEBACTON KTICTHN. На реверсі зображено Тиберія у військових обладунках, який потискає руку Тюхе (RPC 2451; SNG von Aulock 3000; Sear Greek 272). У Capдах магістрати ще більше підкреслили внесок імператора, показавши в композиції на аверсі Тюхе, що стоїть на колінах перед Тиберієм, одягнутим у тогу, який піднімає iï за руку (мал. 21). Легенда називає Тиберія $\Sigma \mathrm{EBA} \Sigma T O \Sigma$ KAI $\Sigma A P E \Omega N$ $\Sigma \mathrm{AP} \triangle \mathrm{IAN} \Omega \mathrm{N}$. На реверсі зображено Лівію зі скіпетром та колосками в руках, що сидить у кріслі у супроводі легенди $\Sigma$ EBA $\Sigma$ TH IOY $\Lambda$ IO $\Sigma$ K $\Lambda$ E $\Omega N$ KAI MEMN $\Omega N$ (RPC I 2991; BMC 98-101; Paris 1205; Waddington 5233; SNG Copenhagen 515-516; Mionnet Supp. VII, 460; GRPC Lydia 355). 

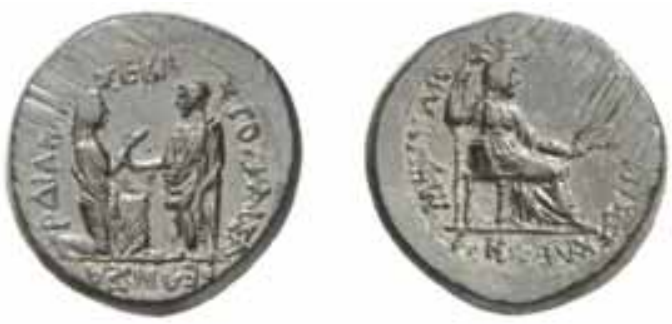

Мал. 21. Імператор Тиберій піднімає Тюхе Сард із колін:

відображення допомоги імператора місту після землетрусу 17 р. н. е.

На реверсі монет Септимія Севера з Гіпайпи імператор з патерою та Тюхе із зображенням Артеміди Анаїти та скіпетром стоять навколо палаючого вівтаря (Imhoof $L S$ 13). На реверсі великої монети вагою 46,67 г з Герме в Місії (мал. 22) постать імператора вміщено в центр композиції, де з лівого боку від нього стоїть Тюхе з рогом достатку, а з правого - Ніке, яка коронує Септимія Севера вінком (SNG France V, 984).
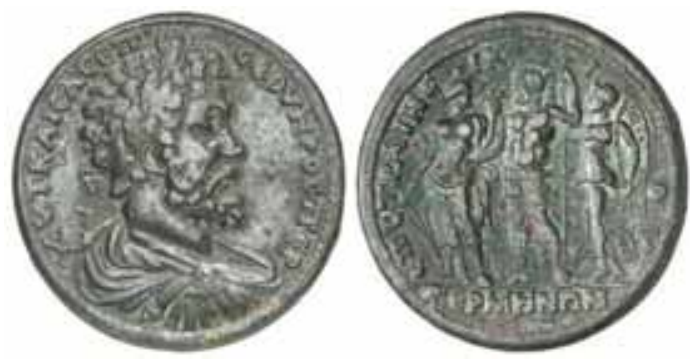

Мал. 22. Тюхе Герме в композиції прославлення імператора Септимія Севера

Образ Тюхе як обов'язкової супутниці чи символу успіху закарбовано в композиції монет Коммода з Мітілени на Лесбосі (мал. 23). Імператор зі списом зображений верхи на коні, Ніке накладає на нього вінець ззаду, а перед конем стоїть Тюхе 3 трофеєм, а під ногами коня розташована зіщулена постать полоненого (BMC 204; Mionnet III 148).
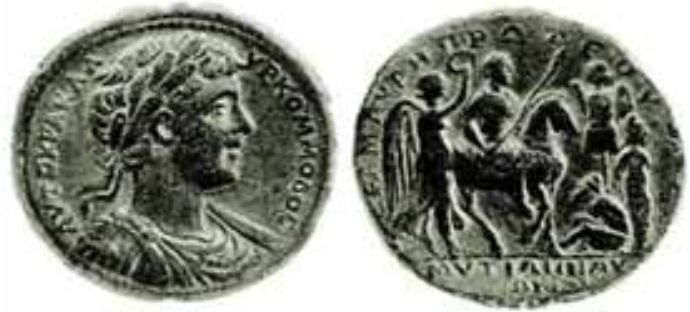

Мал. 23. Образ богині Тюхе в композиції увіковічнення воєнних перемог

На монетах у Сардах часів правління Каракали відзначено момент передачі Тюхе імператору культового зображення Кори. Богиня зображена 3 опущеним скіпетром, а імператор простягає вінець, тримаючи спис (Hirsch 159-856).

Якийсь не до кінця зрозумілий епізод з історії провінції Азія в часи правління Галієна позначено карбуванням монет із погруддям імператора на аверсі та в композиції, де Ніка коронує Тюхе (мал. 24). Такі монети карбувалися в Магнезії над Сипілумом (Mionnet IV 450) та в Саїтті. Саме цей жест коронації $є$ теж дуже знаковим для монетного карбування II-III ст. н. е. 


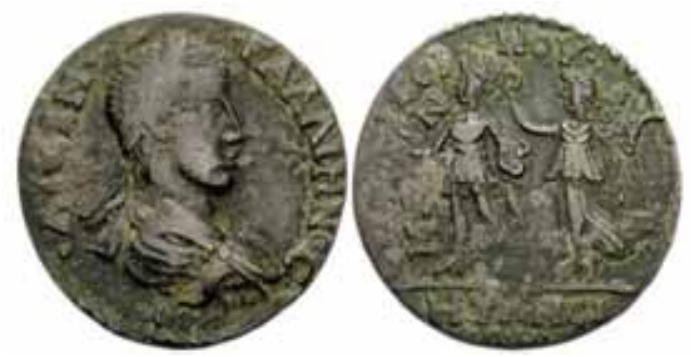

Мал. 24. Богиня Ніке коронує богиню Тюхе

Проведений аналіз монетного матеріалу дає змогу зробити певні висновки. Образ Тюхе-Фортуни як уособлення мінливості вибору широко використовувався в провінційному монетному карбуванні, у різноманітних номіналах. На відміну від інших територій, в Азії погруддя богині набагато рідше прикрашало аверс. Найпопулярнішим були два види оздоблення реверсу: Тюхе з рогом достатку та кермом у руках та погруддя богині в короні з міських мурів. Останній варіант був не завжди типовим і механічно відтворюваним - за особливостями подачі образу можна простежити нюанси міських укріплень та інші архітектурні особливості. Погруддя богині Тюхе в короні з міських мурів використовувалось і як знак у контрмарках. У І ст. н. е. в напівавтономному карбуванні та цивільних випусках монет можна зустріти приклади, коли погруддя Тюхе в міських мурах з одного боку поєднувалося зі статуєю богині з атрибутами з другого. Це можна вважати прикладом підкреслення автономності та відокремлення від офіційного карбування через застосування типово грецького божества.

Божества чи персоніфікація важливих абстрактних понять, прикладом чого й була Тюхе, у монетному карбуванні правили символом, опосередковували владу в регіональних союзах, пов'язували божественну та світську владу.

Вивчення монетного матеріалу дає змогу стверджувати, що, незважаючи на відсутність археологічних свідчень, у провінції Азія існував храм чи храми на честь Тюхе, однак питання його локалізації і вигляду є перспективним для досліджень.

Найчастіше до образу Тюхе звертались магістрати міст Лідії. Передусім ідеться про Фіатиру, Гіпайпу, Магнезію над Сипілумом, Тралли, Філадельфію, Сарди тощо. У монетному карбуванні Місії, Троади та інших областей провінції Азія образ богині використовувався набагато рідше. Цікаво, що такі великі міста, як Пергам та Ефес, дуже рідко використовували цей символ. Тюхе як персоніфікація громадянського колективу міста використовувалася для увіковічнення благодійності імператорів містам чи укладання союзів міст. Щодо часу найбільшої популярності, то це стосується правління імператорів II-III ст. н. е., передусім Каракалли, Елагабала, Септимія та Александра Северів, Гордіана III, Юлії Домни, Траяна та ін., коли карбування монети було засобом боротьби з гіперінфляцією та девальвацією монет. Особливо часто образ богині Тюхе використовувався в міському карбуванні часу кризи III століття, що особливо підкреслює особливості економічних відносин і брак монетної маси в зазначений час.

Загалом аналіз монет показує еволюцію сприйняття образу богині - від покровительки міст до акценту на непостійності богині, яка роздає добро і зло, не зважаючи на заслуги людей чи міст. Також у провінційному карбуванні ії образ підкреслював те, що Тюхе в іпостасі Фортуни чи Немезиди була богинею вибору та справедливої відплати. Можна припустити, що в умовах нестабільної політичної та 
А. Ю. Баукова

економічної ситуації в імперії магістрати провінційних міст Азії через звернення до образу Тюхе-Фортуни намагались підкреслити місцеві цінності та впевненість у доброму майбутньому.

\section{REFERENCES}

Amandry M., Burnett A. and Mairat J. (2015), Roman Provincial Coinage III, From Nerva to Hardian (AD 96-138), British Museum Press and Bibliothèque Nationale, London and Paris.

Babelon E. (1892), La collection Waddington au cabinet des médailles, Rollin et Feuardent, R.N. Paris.

Bellinger A. (1961), Troy: The Coins, Princeton University Press, Princeton.

Feuardent R. and Holzhausen A. (1895), Catalogue de la Collection des Médailles Grecques de M. le Chevalier Léopold Walcher de Molthein, Paris.

Forrer L. (1926), Descriptive Catalogue of the Collection of Greek Coins formed by Sir Hermann Weber, Spink and Son, London.

Franke P. R. and Noellé M. K. (1997), Die Homonoia - Münzen Kleinasiens und der thrakischen Randgebiete, Saarbrücker Druckerei und Verlag, Saarbrücken.

Grose S. (1929), Fitzwilliam Museum: Catalogue of McClean Collection of Greek Coins, Vol. III: Asia Minor, Father Asia, Egipt, Africa, Cambridge University Press, Cambridge.

Head W. (1902), British Museum, Department of Coins and Medals, Catalogue of Greek Coins of Lydia, The Trustees of British Museum, London.

Howgego C. (1985), Greek Imperial Countermarks, Royal Numismatic Society, Special Publication, No. 17, Royal Numismatic Society, London.

Imhoof-Blumer F. (1897), Lydische Stadtmünzen, neue Untersuchungen, Schweizer Numismatisch Gesellschaft and Otto Harrassowitz, Geneva and Leipzig.

Imhoof-Blumer F. (1902), Kleinasiatische Münzen, Hölder, Vienna.

Kapossy B. (1993), Sylloge Nummorum Graecorum, Schweiz II: Katalog der Sammlung Jean-Pierre Righetti im Bernischen Historischen Museum, Haupt, Bern.

Kurth D. (2020), Greek and Roman Provincial Coins - Lydia, Ege Yayinlari, Istanbul.

Mannsperger D. (1994), Sylloge Nummorum Graecorum: Deutschland. Münzsammlung der Universität Tübingen: Heft 5. Karien und Lydien, Gebrüger Mann, Berlin.

Mark Joshua J. Anahita, in World History Encyclopedia, available at: https://www. ancient.eu/Anahita/ (date of access: 20.02.2021).

Mionnet T. (1809), Description de Medailes antiques grecques et romaines, T. IV (Lydia - Armenia), Testu, Paris.

Miano D. (2018), Fortuna: Deity and Concept in Archaic and Republican Italy, Oxford University Press, Oxford.

Naster P. (1959), La collection Lucien de Hirsch. Catalogue des monnaies grecques, Bibliothèque Royale de Belgique, Cabinet des Médailles, Brussels.

Robinson A. (1978), Roman Imperial Coins in the Hunter Coin Cabinet, University of Glasgow, Vol. IV, Oxford University Press, Oxford.

Roman Provincial Coinage Online, available at: http://rpc.ashmus.ox.ac.uk/ (date of access: 10.02 .2021$)$.

Sear D. (1979), Greek Coins and Their Values, Vol. 2: Asia and Africa, Spink Books, London. 
Богиня Тюхе в монетному карбуванні міст римської провінції Азія

Sylloge Nummorum Graecorum (1982), Denmark. The Royal Collection of Coins and Medals, Danish National Museum, Vol. 5: Ionia, Caria and Lydia, Sunrise, West Milford, NJ.

Smyth A. C. (2003), Athenian Political Art from the Fifth and Fourth Centuries BCE: Images of Political Personifications, available at: http:/www.stoa.org/demos/article_personifications@page=25\&greekEncoding=UnicodeC.html (accessed: 10.02.2021).

Sylloge Nummorum Graecorum (1997), Deutschland. München Staatlische Münzsammlung, Part 23: Lydien, Hirmer Verlag, München.

Sylloge Nummorum Graecorum (2001), France. Bibliothéque Nationale, Cabinet des Médailles, Vol. 5: Mysia, Numismatica Ars Classica, Paris.

Sylloge Nummorum Graecorum (1957), Sammlung Hans von Aulock, Vol. 1: Pontus, Paphlagonia, Bithynia, Mysia, Troas, Aiolis, Lesbos, Ionia, Verlag Gebr. Mann, Berlin.

Sylloge Nummorum Graecorum (1947), The Royal Collection of Coins and Medals, Danish National Museum, Munksgaard, Copenhagen.

\section{А. Ю. Баукава \\ БАГІНЯ ЦЮХЕ Ў МАНЕТНАЙ ЧАКАНЦЫ \\ ГАРАДОЎ РЫМСКАЙ ПРАВІНЦЫІ АЗІЯ}

Манеты рымскага часу з'яўляюцца цудоўнай крыніцай для вывучэння палітычнай гісторыі і змен у светапоглядзе пад уздзеяннем розных фактараў. Выявы і сімвалы, змешчаныя на манетах, не толькі гарантавалі іх каштоўнасць, але і былі сродкам зносін, распаўсюджвання уяўленняў аб уладзе-эмітэнце. Паколькі ў вывучаемы перыяд на тэрыторыі рымскай правінцы Азія практыка чаканкі ўжо мела дастаткова значныя традыцыі, то з'яўленне ці інтэрпрытацыя розных бостваў прадстаўляюць выключную цікаўнасць. Не стала выключэннем і постаць багіні Цюхе. Гэта персаніфікацыя долі (звычайна, уласнай добрай долі) мае вельмі даўнія карані ў міфалагічным светапоглядзе, але толькі ў першых стагоддзях нашай эры быў выпрацаваны добравядомы вобраз багіні з рогам багацця ў руках і стырном. Цікава, што з усіх абласцей рымскай правінцыі Азія найперш магістраты Лідзіі звярталіся да вобразу багіні Цюхе. У манетным матэр'яле вызначаецца некалькі тыпаў: пагрудная выява багіні ў кароне з гарадскіх муроў, статуя багіні з рознымі атрыбутамі, персаніфікацыя горада праз Цюхе ў манетах у гонар саюзу гарадоў ды статуя багіні ў тэтрастыльным храме. Манетныя штампы адрозніваюцца якасцю і дэталізацыяй выканання, аднак пагрудная выява багіні ў розных гарадах мае шэраг сходных рыс. Бюст Цюхе ўпершыню сустракаецца на манетах Гіпайпы ў IV ст. да н. э. Важным этапам ушанавання ды яе сімволікі было змяшчэнне выявы на традыцыйных срэбных цыстафорах. Таксама, традыцыйным для манетнай чаканкі антычных грэчаскіх полісаў было аздабленне абедзьвух старон манеты пагруднымі выявамі Цюхе ды яе статуі на звароце. У манетных выявах Цюхе мае агульныя рысы з выявай Кібелы ці Амазонкі ў Смірне. Найчасцей да постаці Цюхе звярталіся магістраты Азіі ў часы III ст. н. э. Уласна кажучы, пастаянная палітычная нестабільнасць і эканамічныя нягоды ў гэты час сталі ўжо звычайнымі, i, таму, сімволіка багіні добрай долі, напэўна, была спробаю паказаць шлях да міру і росквіту. Дзякуючы манетнай чаканцы з вобразам Цюхе можна раканструяваць адносіны паміж асобнымі гарадамі правінцыі і імператарам, паміж гарадамі ўнутры правінцыі. 3'яўленне вобразу Цюхе на кантрамарках дае магчымасць прасачыць колькасць асобных манет у часы змяньшэння манетнай массы і яе абясцэньвання. Выкарыстанне вобразу Цюхе цесна звязана з існаваннем храмаў багіні ды яе паяднаннем з мясцовымі вобразамі: Артэмідаю Анайтаю, Кораю, Апалонам Цірымнейскім ды іншымі.

Ключавыя словы: багіня Цюхе, рымская правінцыя Азія, чаканка манет, кантрамарка, імператар, крызіс III ст. н. э. 


\section{БОГИНЯ ТЮХЕ В МОНЕТНОМУ КАРБУВАННІ МІСТ РИМСЬКОЇ ПРОВІНЦІЇ АЗІЯ}

Монети римського часу є чудовим джерелом для вивчення політичної історії та змін у світогляді під дією різних чинників. Зображення та символи, вміщені на монетах, не тільки гарантували їхню цінність, а й були засобом спілкування чи поширення уявлення про владу-емітента. Оскільки в досліджувану добу на території римської провінції Азія практика карбувати монети вже мала значні традиції, то поява чи інтерпретація різних божеств становлять значний інтерес. Не стала винятком і постать богині Тюхе. Ця персоніфікація долі (як правило, власне доброї долі) має дуже давнє коріння в міфологічному світогляді, але тільки в перших століттях нашої ери вироблено добре впізнаваний образ богині з рогом достатку в руках та кермом. Цікаво, що з усіх областей римської провінції Азія до образу богині Тюхе звертались передусім магістрати Лідії. У монетному матеріалі виділяється кілька типів: погруддя богині в короні з міських мурів, статуя богині з різними атрибутами, персоніфікація міста через Тюхе в монетах на честь союзу міст та статуя богині в тетрастильному храмі. Монетні штампи різняться якістю та деталізацією виконання, однак погруддя богині в різних містах має низку спільних рис. Погруддя Тюхе вперше зустрічається на монетах Гіпайпи в IV ст. до н. е. Важливим етапом вшанування богині та іiі символіки було вміщення зображення на традиційних срібних цистофорах. Також традиційним для монетного карбування античних грецьких полісів було й оздоблення обох сторін монет погруддям Тюхе та їі статуєю на звороті. У монетному зображенні Тюхе має спільні риси із зображенням Кібели чи Амазонки в Смірні. Найчастіше до постаті Тюхе звертались магістрати Азії в часи кризи III ст. н. е. Власне, постійна політична нестабільність та економічні негаразди в цей час стали уже звичними, і тому символіка богині доброї долі, ймовірно, була спробою показати шлях до миру і процвітання. Завдяки монетному карбуванню 3 образом Тюхе можна реконструювати відносини поміж окремими містами провінції та імператором, поміж містами всередині провінції. А поява образу Тюхе в контрмарках дає змогу простежити долю окремих монет у часи зменшення монетної маси і її знецінення. Також важливим аспектом використання образу Тюхе $є$ існування храмів богині та ії поєднання 3 місцевими божествами - Артемідою Анаїтою, Корою, Аполлоном Тиримнейським та ін.

Ключові слова: богиня Тюхе, римська провінція Азія, карбування монет, контрмарка, імператори, криза III століття 